\title{
VERBA MEMOTONG BAHASA ROTE DIALEK DENGKA: KAJIAN META SEMANTIK ALAMI (MSA)
}

\author{
Efron Erwin Yohanis Loe \\ STIBA MENTARI KUPANG \\ efronloe@yahoo.com
}

\begin{abstract}
Abstrak
Artikel ini menganalisis penggunaan kata kerja "memotong" dalam Bahasa Rote Dialek Dengka. Dari hasil wawacara dengan narasumber diperoleh sebelas leksikon "memotong" yang dijelaskan dalam bagian pembahasan. Kesebelas kata kerja "memotong" yaitu: soe, o?oti, pgute, ba?e, tati, unga, teta, ga?e, ete, fa?a, dan pa. Pendekatan teori yang digunakan untuk menganalisis kesebelas kata kerja "memotong" Bahasa Rote Dialek Dengka adalah Metabahasa Semantik Alami (MSA). Dengan pendekatan MSA pencapaian hasil analisis kesebelas leksikon menjadi maksimal karena setiap satu makna diperuntukan satu leksikon.
\end{abstract}

Kata kunci: kata kerja, memotong, bahasa Rote, dialek Dengka

\begin{abstract}
This article analyzes the use of verb "cut"in Dengka Dialectof Rote Language. Based on the data collections obtained from the informen, there are eleven lexicons discovered and described one by

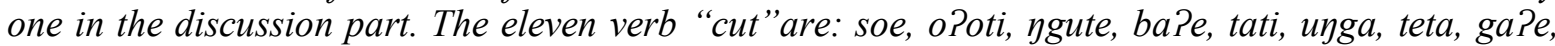
ete, fa $\mathrm{Pa}$ and $\mathrm{pa}$. The approach applied to analize those elevent lexicons is natural semantics metalanguage (NSM). By using the approach, the analysis obtained become maximized since there is one meaning for each lexicon.
\end{abstract}

Keywords: verb, to cut, Rote language, Dengka dialect

\section{PENDAHULUAN}

Bahasa mengemban misi yang sangat vital dalam seluruh aspek kehidupan manusia. Bahasa berperan sebagai sarana untuk mengkomunikasikan seluruh kegiatan yang dilakukan oleh manusia sepanjang hari sejak pagi hingga malam hari. Hal ini menyebabkan manusia tidak terpisahkan dari bahasa. Bahasa membentuk pola pikir manusia untuk menghasilkan dan mengimplementasikan berbagai gagasan.

Berbagai gagasan yang diungkapkan melalui bahasa diupayakan untuk keberlangsungan hayat hidup manusia, sebab dengan bahasa manusia dapat berko- munikasi dan membangun interaksi dengan sesama untuk membentuk suatu kerjasama dalam berbagai bidang dan aspek kehidupan seperti salah satunya dalam bidang kemasyarakatan. Kridalaksana (2008:24) mengatakan bahwa, bahasa adalah sistem lambang bunyi yang dipergunakan oleh para anggota suatu masyarakat untuk bekerja sama, berinteraksi dan mengidentifikasikan diri. Bahasa tidak hanya berfungsi sebagai alat komunikasi tetapi bahasa juga memiliki seperangkat kaidah yang harus ditaati oleh manusia sebagai pemilik dan pengguna dari bahasa itu sendiri.

Dalam bidang kajian linguistik mikro, bahasa dibagi ke dalam empat tataran, yak- 
ni: fonologi (ilmu bunyi), morfologi (ilmu bentuk kata), sintaksis (ilmu bentuk kalimat) dan semantik (kajian makna bahasa). Keempat sub bagian tersebut merupakan satu kesatuan yang tidak dapat dipisahkan dari bahasa karena semua bahasa di dunia ini baik bahasa dengan jumlah penutur terbesar dan bahasa dengan jumlah penutur yang sangat sedikit akan terbentuk oleh keempat komponen tersebut.

Berbicara tentang makna, bidang kajiannya adalah semantik sebagai ilmu yang membahas makna bahasa. Verhaar (2008:13) menyatakan bahwa semantik adalah cabang dari linguistik yang membahas arti atau makna. Selain itu, Kridalaksana (2008:216) menyatakan bahwa semantik adalah bagian struktur bahasa yang berhubungan dengan makna ungkapan dan juga dengan struktur makna suatu wicara.

Pendekatan yang digunakan untuk melakukan analisis makna dari setiap leksikon memotong dalam bahasa Rote dialek Dengka (selanjutnya disingkat BRDD) adalah Metabahasa Semantik Alami (MSA). BRDD adalah rumpun bahasa Malay Polinesia tengah yang bertipe aglutinasiyang dipergunakan di Pulau Rote, Kecamatan Rote Barat Laut, Kabupaten Rote Ndao, Provinsi Nusa Tenggara Timur sebagai penutur terbanyak dari dialek ini. Teori MSA ini diakui sebagai pendekatan kajian semantik yang relatif moderen dan mampu memberi hasil analisis makna yang memadai. Hal ini disebabkan oleh penggunaan teknik eksplikasi dalam MSA sehingga hasil analisis makna pada suatu bahasa telah mendekati postulat ilmu semantik yang menyatakan bahwa satu bentuk untuk satu makna dan satu makna untuk satu bentuk. Dengan kata lain, satu butir leksikon mampu mewahanai satu makna atau, satu makna diungkapkan dengan satu butir leksikon. Hal ini akan menghindarkan dari pemerian makna yang berputar-putar terhadap satu leksikon (Sudipa 2010).

Dalam menganalisis verba memotong BRDD dengan pendekatan teori MSA, ditetapkan satu asumsi bahwa $\mathrm{X}$ sebagai subjek melakukan suatu tindakan memotong yang diinginkannya, menurut alat yang digunakan untuk memotong, hasil pemotongan, gerakkan dalam proses pemotongan, dan bagian entitas yang dikenai perlakuan memotong serta hasil akhir yang ingin dicapai atau yang diharapkan oleh $\mathrm{X}$ terhadap Y sebagai obyek dan Ymengalami sesuatu atas tindakan memotong yang dilakukan oleh X.

Kata kerja "memotong" dalam BRDD terdiri atas sebelas leksikon, yaitu soe, o?oti, ngute, ba?e, tati, unga, teta, ga?e, ete, faPa, dan pa. Kesebelas leksikon tersebut memiliki kedekatan dalam satu medan makna yang sama yaitu memotong, namun alat yang dipergunakan dan objeknya berbeda. Di bagian pembahasan akan dijelaskan penggunaan dari setiap leksikon "memotong" BRDD secara rinci. 
2. KONSEP DAN KERANGKA TEORI KONSEP

\section{Verba}

Verba atau kata kerja adalah kelas kata yang biasanya berfungsi sebagai predikat; dalam beberapa bahasa lain verba mempunya ciri morfologis seperti ciri kala, aspek, persona atau jumlah. Sebagian besar verba atau kata kerja memiliki unsur semantis perbuatan, keadaan, atau proses; kelas ini dalam bahasa Indonesia ditandai dengan kemungkinan untuk di awali dengan kata tidak dan tidak mungkin di awali dengan kata seperti sangat, lebih, dsb; misalnya datang, naik, bekerja, dsb (Kridalaksana, 2008:254).

\section{Bahasa}

Keraf (1979:1) dalam bukunya berjudul Komposisi mendefinisikan Bahasa adalah alat komunikasi antara anggota masyarakat berupa simbol bunyi yang dihasilkan oleh alat ucap manusia. Selanjutnya Finochiaro (1974:3), dan Wardhaugh (1972:3) mereka berpendapat bahwa bahasa adalah suatu sistem arbitrer atau simbol-simbol yang semenayang memungkinkan semua warga dalam satu kebudayaan tertentu atau orang lain yang sudah mempelajari sistem kebudayaan itu untuk dapat berkomunikasi dan berinteraksi (Language is a system of arbitrary, vocal symbols which permits all people in a given culture or other people who have learned the system of that culture to communicate or to interact).

\section{Dialek}

Menurut Kridalaksana (2008:48) dialek didefnisikan sebagai variasi bahasa yang berbeda-beda menurut pemakai; variasi bahasa yang dipakai oleh kelompok bahasawan di tempat tertentu (dialek regional), atau oleh golongan tertentu dari suatu kelompok bahasawan (dialek sosial), atau oleh kelompok bahasawan yang hidup dalam waktu tertentu (dialek temporal). Contoh dialek regional ialah Bahasa Melayu Riau, contoh dialek sosial ialah Bahasa Melayu yang dipakai oleh para bangsawan, dan contoh dialek temporal ialah Bahasa Melayu Klasik.

\section{KERANGKA TEORI}

Pendekatan teori NSM, telah banyak dipergunakan terhadap bahasa-bahasa di dunia seperti bahasa-bahasa Lao (Thailand), Mangaaba-Mbula, Malaysia (Auatronesia), China, Mandarin, Polandia, Spanyol, Inggris, Kreol, Hawaii, Aceh, Jepang dan beberapa bahasa asli Aborigin di Australia, seperti: Bunuba, Yankunytjajara. (Goddard, 2002:12).

Teori NSM yang diterjemahkan dalam bahasa Indonesia "Metabahasa Semantik Alami” (MSA) dipandang sangat cocok pula untuk dipakai dalam menganalisis DD karena dapat menjelaskan setiap bentuk makna asali dengan baik. (Wierzbicka, 1996:10; Mulyadi 2012:33; Sudipa 2004) asumsi dasar bertalian dengan prinsip semiotik, seperti dalam kutipan berikut: " $A$ sign cannot be reduced to or analyzed into any 
combination of things which are not themselves signs; consequently, it is imposible to reduce meanings to any combination of things which are not them selves meanings" (Wierzbicka, 1996:10). Hasil terjemahan kutipan "Sebuah tanda tidak bisa direduksi atau dianalisis menjadi berbagai kombinasi sesuatu apapun yang bukan bagian dari tanda-tanda itu sendiri; akibatnya tidaklah mungkin mereduksi berbagai makna menjadi kombinasi sesuatu apapun yang bukan merupakan bagian maknanya sendiri”.

Teori MSA dalam kajian semantik bukan saja sebagai teori yang mutakhir yang relatif moderen dalam menganilisis makna, tetapi satu pendekatan teori yang mampu memberikan hasil analisis yang memadai dalam setiap makna asali dari setiap bahasa yang menggunakan pendekatan teori ini.

\section{PEMBAHASAN}

Dalam bagian pembahasan akan dibahas penggunaan dari setiap leksikon BRDD dengan pendekatan teori MSA yang telah dijelaskan pada bagian pendekatan teori di atas. Selanjutnya penerapan teori semantik MSA akan dipergunakan dalam membahas kesebelas kata kerja (verba) BRRDD, yakni: soe, o?oti, ygute, ba?e, tati, unga, teta, ga?e, ete, fa?a, dan pa. Kesebelas leksikon tersebut memiliki medan makna dalam bahasa Indonesia yaitu "Memotong", dengan rincian dalam pembahasan sebagai berikut:

a. soe

Kata kerja 'soe' BRDD dapat dilakukan oleh setiap orang, pria, wanita, anak-anak, dan orang tua. Alat yang dipergunakan berupa sebilah pisau kecil tajam dengan ujungnya yang runcing. Tindakan ini dilakukan dengan cara menekan ujung pisau atau bagiannya yang tajam sambil menarik ke belakang atau mendorong ke depan sesuai dengan hasil yang diinginkan. Hal ini dilakukan secara berulang-ulang pada objeknya berupa bawang, lombok, daun tembakau, kertas, daun, dan bunga. Entitas yang dikenai adalah seluruh bagian dari objek, dan akan menyebabkan objek terpotong-potong dalam bentuk irisan kecil-kecil dan tipis.

Kata kerja (verba) 'soe' BRDD, dapat dieksplikasikan sebagai berikut:

$\mathrm{X}$ melakukan sesuatu tindakan pada $\mathrm{Y}$ pada saat yang bersamaan sesuatu terjadi pada $\mathrm{Y}$

$\mathrm{X}$ melakukan dengan cara tertentu (menarik lurus ke belakang atau mendorong lurus ke depan dilakukan langsung dan berulang-ulang pada Y)

$\mathrm{X}$ melakukan dengan alat (sebila pisau kecil dan tajam)

$\mathrm{X}$ melakukannya berulang-ulang

Y menjadi potongan kecil-kecil dan tipis

$\mathrm{X}$ mengingini hal ini 
X melakukannya tepat seperti yang diinginkannya

b. oPoti

Kata kerja 'o?oti' BRDD dapat dilakukan oleh setiap orang, pria, wanita, anak-anak, dan orang tua. Alat yang dipergunakan berupa sebilah parang dan sabit yang tajam. Tindakan ini dilakukan dengan cara mengayunkan tangan ke depan ke arah target sesuai dengan hasil yang diinginkan dengan alat ditangan. Hal ini dilakukan berulang-ulang pada objeknya seperti rumput. Entitas yang dikenai adalah seluruh bagian dari objek, dan akan menyebabkan objek terpotong-potong putus dan rata dengan tanah.

Kata kerja (verba) 'o?oti' BRDD, dapat dieksplikasikan sebagai berikut:

$\mathrm{X}$ melakukan sesuatu tindakan pada $\mathrm{Y}$

pada saat yang bersamaan sesuatu terjadi pada $\mathrm{Y}$

$\mathrm{X}$ melakukan dengan cara tertentu (mengayunkan tangan ke depan

dilakukan langsung dan berulang-ulang pada Y)

$\mathrm{X}$ melakukan dengan alat (sebila parang dan sabit)

$\mathrm{X}$ melakukannya berulang-ulang

Y menjadi terpotongputus dan rata dengan tanah

$\mathrm{X}$ mengingini hal ini

$\mathrm{X}$ melakukannya tepat seperti yang diinginkannya

\section{c. ygute}

Kata kerja 'ngute' BRDD dapat dilakukan oleh setiap orang, pria, wanita, anak-anak, dan orang tua. Alat yang dipergunakan berupa sebuah gunting. Tindakan ini dilakukan dengan cara menggunting pada sehelai kertas, kain, rambut, ujung bunga, dedaunan dan bunga sesuai dengan hasil yang diinginkan dan tindakan ini dilakukan berulang-ulang pada objeknya. Entitas yang dikenai adalah seluruh bagian dari objek, dan akan menyebabkan objek terpotong-potong sesuai dengan yang diinginkannya.

Kata kerja (verba) 'ngute' BRDD, dapat dieksplikasikan sebagai berikut:

$\mathrm{X}$ melakukan sesuatu tindakan pada $\mathrm{Y}$ pada saat yang bersamaan sesuatu terjadi pada $\mathrm{Y}$

$\mathrm{X}$ melakukan dengan cara tertentu (menggunting dilakukan langsung dan berulang-ulang pada $\mathrm{Y}$ )

$\mathrm{X}$ melakukan dengan alat (sebuah gunting)

X melakukannya berulang-ulang

Y menjadi terpotong-potong

$\mathrm{X}$ mengingini hal ini

$\mathrm{X}$ melakukannya tepat seperti yang diinginkannya 
d. ba?e

Kata kerja 'ba?e' BRDD dapat dilakukan oleh setiap orang, pria, wanita, anak-anak, dan orang tua. Alat yang dipergunakan berupa sebilah pisau, parang dan gergaji. Tindakan itu dilakukan dengan cara menekankan ujung pisau, parang dan gergaji sambil menarik ke belakang atau Kata kerja (verba) 'ba?e' BRDD, dapat dieksplikasikan sebagai berikut:

$\mathrm{X}$ melakukan sesuatu tindakan pada $\mathrm{Y}$ pada saat yang bersamaan sesuatu terjadi pada $\mathrm{Y}$

$\mathrm{X}$ melakukan dengan cara tertentu (menarik lurus ke belakang atau mendorong lurus ke depan dilakukan langsung dan berulang-ulang pada Y)

$\mathrm{X}$ melakukan dengan alat (sebuah pisau, parang dan gergaji)

$\mathrm{X}$ melakukannya berulang-ulang

Y menjadi potongan-potongansesuai dengan hasil yang diinginkan

$\mathrm{X}$ mengingini hal ini

$\mathrm{X}$ melakukannya tepat seperti yang diinginkannya

e. tati

Kata kerja 'tati' BRDD dapat dilakukan oleh setiap orang, pria, wanita, anak -anak, dan orang tua. Alat yang dipergunakan berupa sebilah parang tajam. Tindakan ini dilakukan dengan cara mengayunkan tangan ke depan sambil menekan

Kata kerja (verba) 'tati' BRDD, dapat dieksplikasikan sebagai berikut:

$\mathrm{X}$ melakukan sesuatu tindakan pada $\mathrm{Y}$ pada saat yang bersamaan sesuatu terjadi pada $Y$

$\mathrm{X}$ melakukan dengan cara tertentu (mengayunkan tangan ke depan langsung pada $\mathrm{Y}$ )

$\mathrm{X}$ melakukan dengan alat (sebuah parang tajam)

$\mathrm{X}$ melakukannya hanya sekali saja

Y menjadi terpotong putus dari pokoknya

$\mathrm{X}$ mengingini hal ini

$\mathrm{X}$ melakukannya tepat seperti yang diinginkannya 


\section{f. unga}

Kata kerja 'unga' BRDD hanya dapat dilakukan oleh kaum pria (dewasa). Alat yang dipergunakan berupa sebuah kapak besar dan tajam. Tindakan ini dilakukan dengan cara mengayunkan tangan dengan alat ditangan sambil menekan ke depan sesuai dengan hasil yang diinginkan. Hal ini dilakukan berulang-ulang pada objeknya seperti pohon yang besar atau batang kayu yang besar. Entitas yang dikenai adalah bagian pangkal atau pokoknya dan menyebabkan objek terpotong putus dari pangkalnya.

Kata kerja (verba) 'unga' BRDD, dapat dieksplikasikan sebagai berikut:

$\mathrm{X}$ melakukan sesuatu tindakan pada $\mathrm{Y}$

pada saat yang bersamaan sesuatu terjadi pada $\mathrm{Y}$

$\mathrm{X}$ melakukan dengan cara tertentu (mengayunkan tangan ke depan

dilakukan langsung dan berulang-ulang pada Y)

$\mathrm{X}$ melakukan dengan alat (sebuah kapak besar dan tajam)

$\mathrm{X}$ melakukannya berulang-ulang

Y menjadi tepotong putus dari pangkalnya

$\mathrm{X}$ mengingini hal ini

$\mathrm{X}$ melakukannya tepat seperti yang diinginkannya

g. teta

Kata kerja 'teta' BRDD dilakukan oleh seseorang baik pria, wanita, dan orang tua dengan alat yang digunakan berupa sebuah parang atau pisau besar yang tajam dilakukan dengan cara mencincang sesuai dengan hasil yang diinginkan. Tindakan ini dilakukan berulang-ulang pada objek dan entitas yang dikenai adalah seluruh bagian tubuh dan akan menyebabkan objek menjadi bagian kecil-kecil sesuai dengan hasil yang diinginkannya.

Kata kerja 'teta' BRDD, dapat dieksplikasikan sebagai berikut:

$\mathrm{X}$ melakukan sesuatu tindakan pada $\mathrm{Y}$ pada saat yang bersamaan sesuatu terjadi pada $\mathrm{Y}$

X melakukan dengan cara tertentu (mencincang dan langsung)

$\mathrm{X}$ melakukan dengan alat (parang atau pisau besar)

$\mathrm{X}$ melakukan beulang-ulang

Y menjadi potongan kecil-kecil

$\mathrm{X}$ mengingini hal ini

$\mathrm{X}$ melakukannya tepat seperti ini 
h. ga?e

Kata kerja 'ga?e' BRDD dapat dilakukan oleh setiap orang, pria, wanita, anak-anak, dan orang tua. Alat yang dipergunakan berupa sebuah pisau kecil dan sabit yang tajam. Tindakan ini dilakukan dengan cara menekan pisau atau sabit yang diikat di ujung sebatang kayu pada pangkal objek lalu menarik ke bawah sesuai dengan hasil yang diinginkan. Hal ini dilakukan hanya sekali saja pada objeknya seperti mengambil daun pisang atau buah. Entitas yang dikenai adalah bagian pangkal dari objek dan akan menyebabkan objek terpotong putus dari pangkalnya.

Kata kerja'ga Pe' BRDD, dapat dieksplikasikan sebagai berikut:

$\mathrm{X}$ melakukan sesuatu tindakan pada Y

pada saat yang bersamaan sesuatu terjadi pada $Y$

$\mathrm{X}$ melakukan dengan cara tertentu (menarik turun ke bawah dilakukan

langsung dan hanya sekali pada Y)

$\mathrm{X}$ melakukan dengan alat (sebilah pisau kecil dan sabit tajam)

$\mathrm{X}$ melakukannya hanya sekali

Y menjadi terpotong putus dari pangkalnya

$\mathrm{X}$ mengingini hal ini

$\mathrm{X}$ melakukannya tepat seperti yang diinginkannya

i. ete memutuskan objek (mematahkan ke

Kata kerja 'ete' BRDD dapat dipergunakan untuk memotong namun tidak membutuhkan alat yang tajam seperti pisau atau parang. 'Ete' menggunakan tangan untuk memutuskan sesuatu seperti buah sirih tindakan ini dapat dilakukan oleh setiap orang, pria, wanita, anak-anak, dan bawah) dengan tumpuan pada ujung jari kedua tangan sesuai dengan hasil yang diinginkan. Hal itu dilakukan berulang-ulang pada objeknya. Entitas yang dikenai adalah seluruh bagian dari objek, dan akan menyebabkan objek terpotong-potong dalam bentuk irisan kecil-kecil.

orang tua. Hal ini dilakukan dengan cara

Kata kerja 'ete' BRDD, dapat dieksplikasikan sebagai berikut:

$\mathrm{X}$ melakukan sesuatu tindakan pada $\mathrm{Y}$.

pada saat yang bersamaan sesuatu terjadi pada $Y$

$\mathrm{X}$ melakukan dengan cara tertentu (tumpuan pada ujung jari kedua tangan

dan menekan kebawah, dilakukan langsung dan berulang-ulang padaY)

Y menjadi potongan kecil-kecil

$\mathrm{X}$ mengingini hal ini

$\mathrm{X}$ melakukannya tepat seperti yang diinginkannya 
j. pa

Kata kerja 'pa' BRDD dapat dilakukan oleh setiap orang, pria, wanita, anak-anak, dan orang tua. Alat yang dipergunakan berupa sebuah kapak. Tindakan ini dilakukan dengan cara mengayunkan kapak dari atas dan menekan pada

Kata kerja atau verba'pa' BRDD, dapat dieksplikasikan sebagai berikut:

$\mathrm{X}$ melakukan sesuatu tindakan pada $\mathrm{Y}$ pada saat yang bersamaan sesuatu terjadi pada $Y$

$\mathrm{X}$ melakukan dengan cara tertentu (mengayunkan kapak dari atas dan menekan dilakukan langsung dan hanya sekali pada Y)

$\mathrm{X}$ melakukan dengan alat (sebuah kapak)

$\mathrm{X}$ melakukannya hanya sekali

Y menjadi terpotong putus dari pangkalnya

$\mathrm{X}$ mengingini hal ini

$\mathrm{X}$ melakukannya tepat seperti yang diinginkannya

\section{Peta Pulau Rote}

Sebelum masuk dalam bagian simpulan akan diperlihatkan pada pembaca peta Pulau Rote dan letak-letak kecamatannya serta letak wilayah penggunaan BRDD. BRDD adalah salah satu dari 18 variasi dialek Bahasa Rote dengan penutur sebatang kayu. Hal itu dilakukan hanya sekali saja pada objeknya seperti pada tunggul pohon yang sudah kering. Entitas yang dikenai adalah semua bagian dari objek, dan akan menyebabkan objek terpotong putus dari pangkalnya.

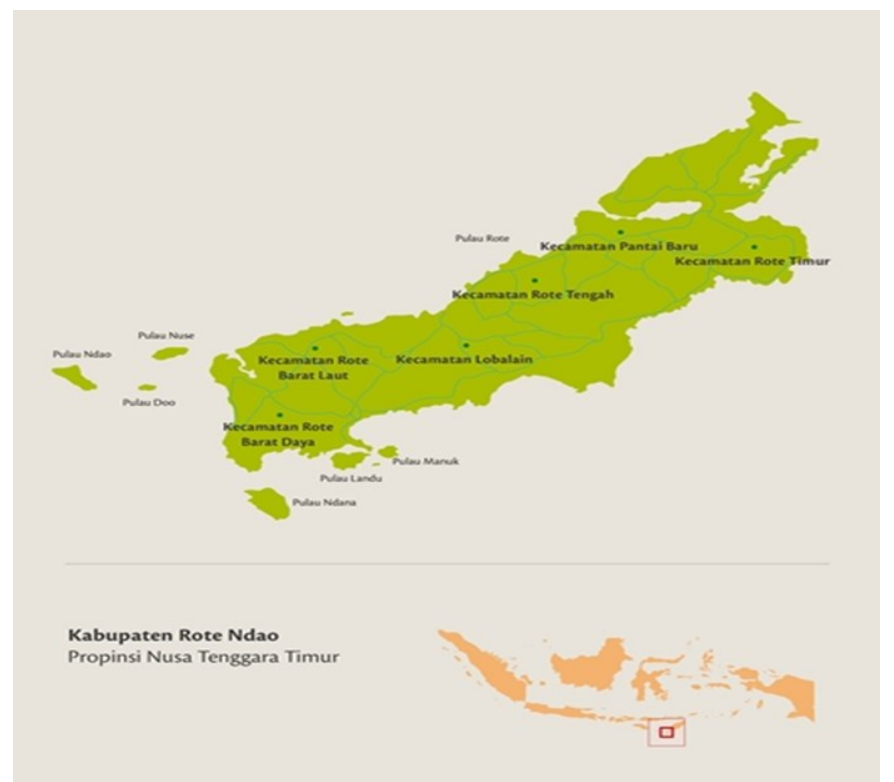




\section{SIMPULAN}

Hasil analisis menunjukkan bahwa, data lingual kata kerja 'memotong' dalam BRDD, yakni soe, o?oti, ygute, ba?e, tati, unga, teta, ga?e, ete, faPa, dan pa. Pendekatan yang dipergunakan yakni MSA (Metabahasa Semantik Alami). Dalam analisis tercermin bahwa pendekatan MSAmemaknai secara tuntas setiap leksikon kata kerja (verba) 'memotong' BRDD dengan teknik eksplikasi walaupun setiap leksikon tersebut di atas memiliki hubungan yang sangat dekat dalam satu medan makna yang sama yaitu 'memotong'.

\section{UCAPAN TERIMA KASIH}

Penulis menyampaikan ucapan terima kasih kepada Dewan Editor Jurnal Retorika Program Magister Linguistik Universitas Warmadewa atas kesempatan yang diberikan pada penulis untuk dapat menerbitkan tulisan ini. Ucapan terima kasih juga penulis haturkan untuk senior dan sahabat penulis Dr. I Wayan Budiarta, S.S., M.Hum, atas segala dukungannya pada penulis.

\section{DAFTAR PUSTAKA}

Finochiaro, M. 1974. English as a Second Language: A Survey of Basic Concepts and Implication. New York: John Wiley \& Sons.

Goddard, Cliff. 1996. Semantics Theory and Semantics Universal (Cliff Goddard Convenor) Cross Linguistics Syntax from Semantics Poin of View (NSM Approach) 1-5 Australia.

Goddard, Cliff. 2002. The Search for the Shared Semantics Core of All Language. Australia: University of New England.

http://www.rotendaokab.go.id

Kridalaksana, Harimukti. 2008. Kamus Linguistik. Edisi Keempat: PT Gramedia
Pustaka Utama Jakarta.

Keraf, Goris. 1979. Komposisi. Flores: Nusa Indah.

Mulyadi. 1998. "Struktur Semantik Verba Bahasa Indonesia" Tesis S2. Linguistik Denpasar

Sudipa. I Nengah. 2010. Struktur Semantik Verba Bahasa Bali "Masarë-Majujuk". Disajikan pada Seminar Internasional Bahasa dan Budaya Austronesia V, Juli 2010. Denpasar.

Sutjiati-Berata, NL. 1997. "Basic Concepts of a Universal Semantics Metalanguage" Lingusitika. 110-115. Denpasar Program Magister Linguistik UNUD.

Verhaar. J.W.M. 2008. Asas-Asas Linguistik Umum. Yogyakarta: Gaja Mada University Press.

Wierzbicka, Anna. 1996. Semantics: Primes and Universal. Oxford: Oxford University Press

Wierzbicka, Anna. 1987. English Speech Act Verbs. Sydney: Academic Press.

Wardhaugh, R. 1972. Introduction to Lingusitics. New York: McGrouh-Hill. 